\title{
ヒト直立時重心動摇図の年齢変化 †
}

\author{
八木一記*・藤 野明人・徳增厚二 \\ 伊保清子・米田敏
}

緒言

重心動摇検查は, 立直り反射検査の一つとして，その 重要性が認識され, 検查で得られる種々のパラメータの 意義も判明しつつある1)。しかしながら，年齢などの正 常域の設定を含めその基準化はいまだ確立されていな い。

今回, 正常被検者のロンベルグ姿勢直立時重心動摇検 查で, 動摇軌跡距離, 動摇面積, 左右方向および前後方 向動摇最大幅の測定值ならびに周波数分析結果について 年齢を考慮して検討した。

\section{研究対象}

正常者の重心動摇軌跡距離, 動摇面積, 左右方向抢上 び前後方向動摇最大幅の測定は, 昭和60年 8 月, 9 月の 北里大学病院人間ドック受診者 229 名 (30-71 歳, 男性 153 名, 女性 76 名), 学生及び検査技師71名（20歳代, 男性31名, 女性40名), 計 300 名を対象とした。周波数分 析については健康青壮年者 20名（18-49歳, 男性 13名, 女性 7 名) 之健康高㱓者 10名 (65-78歳, 男性 5 名, 女性 5 名）の両群について比較検討した。

\section{研究方法}

体重補正つきの重心動摇計（パテラ S110-A）を使用 した。

周囲は静かで明るく (照度 980 lux), 特に方向を認知 させる音や光は除いた。被検者に $2 \mathrm{~m}$ 前方で目の高さに 合わせた径 $1.5 \mathrm{~cm}$ の十字型の赤色固定指標の中心を注 視させ, 裸足または靴下のまま両足内縁を接した閉足位 で，両側上肢は軽く体側に接した自然の直立姿勢, 即ち ロンベルグ姿勢で，水平位に固定した検査台上に直立さ せ，開眼 60 秒と，軽く眼瞼を閉じた閉眼 60 秒で測定し た。

重心動摇軌跡距離, 動摇面積, 左右方向および前後方 向動摇最大幅の平均値, $95 \%$ 信頼限界上限（片側検定） を男女別の $20 ， 30 ， 40 ， 50$ 歳代及び60歳以上の各年代ご とに, 開眼, 閉眼のそれぞれの条件下で求めた。

$\uparrow$ Study on Stabilometry in Normal Upright Standing - the Change depending on Age-grade--

* Kazunori Yagi, Akito Fujino, Kohji Tokumasu, Kiyoko Iho, Satoshi Yoneda

$*$ 北里大学医学部耳鼻咽喉科学教室 動摇軌跡距離（mm）は重心動摇計より直接読及取り, 左右方向括よび前後方向動摇最大幅 $(\mathrm{mm})$ はY レュ ーダ上に記録した重心動摇図より計測した。動摇面積 $\left(\mathrm{mm}^{2}\right)$ は重心動摇図の最大外周で囲まれた図の面積を 自動プラニメータ（タマヤプラニックスセブン）で2回 測定しそれを平均した2)。周波数分析は，データレコー ダに記録した左右，前後方向の動摇波形を $10 \mathrm{~Hz}$ low pass filter を通し, シグナルプロセッサー（三栄 7T08） により FFT 方式で実施した。解析時間 $51.2 \mathrm{sec}$, サン プリング時間間隔 $50 \mathrm{msec}$, 分解能 $0.0195 \mathrm{~Hz}$ で，ハ ワースペクトラムを求め, それを更にルート変換し振幅 スペクトラム值として測定した。解析方法は $10 \mathrm{~Hz}$ 以 下の周波数を 0-0.5070 Hz, 0.5070-1.0100 Hz, 1.0140$2.0085 \mathrm{~Hz}, \quad 1.9890-3.0030 \mathrm{~Hz}, 3.0030-4.0170 \mathrm{~Hz}, 4.0$ $170-5.0115 \mathrm{~Hz}, 5.0310-9.9450 \mathrm{~Hz}$ の 7 周波数帯域に分 け, $10 \mathrm{~Hz}$ 迄の総振幅值に対するおのおのの周波数帯域 の振幅値の和の比を百分率として表し, その平均值と標 準偏差を求めた ${ }^{3)}$ 。

\section{結果}

表 1 から 4 亿，それぞれ，重心動摇軌跡距離，動摇面 積, 左右方向抒よび前後方向動摇最大幅について, 各年 齢ごとの男女別に開閉眼時とれぞれの平均值, 標準偏差 と95\%信頼限界上限（Xu）を示した。周波数分析につ いては, 表 5 , 表 6 に, それぞれ, 左右方向, 前後方向 の動摇に拈ける各周波数带域での百分率の平均值と標準 偏差を 18 歳から 49 歳までの若壮年者群（以下A群とす る）と65歳から 78 歳までの高㱓者群（以下 B 群とする） について開眼時と閉眼時に分けて示した。

\section{1. 重心動摇軌跡距離}

信頼限界上限は60歳未満で最大值を示したものは開眼 $887 \mathrm{~mm}$, 閉眼 $1840 \mathrm{~mm}$ で, 60歳以上の開眼 $1475 \mathrm{~mm}$, 閉眼 $2075 \mathrm{~mm}$ より小さかった。60歳以上の平均值に対 してその差が有意 $(\mathrm{t}$ 検定, $\mathrm{P}<0.05)$ 亿減少した年代 は, 開眼時飞拈いて, 男性の $20,30,40$ 歳代, 女性の 30，40歳代であった。閉眼時に抢いては，男性の20，40 歳代，女性の30歳代で有意に減少した（表 1 )。

\section{2. 動摇面積}

信頼限界上限は60歳未満で最大は, 開眼 $466 \mathrm{~mm}^{2}$, 閉 眼 $1051 \mathrm{~mm}^{2}$ であり，60歳以上では，それぞれ，534 
表 1 正常者の重心動摇軌跡距離

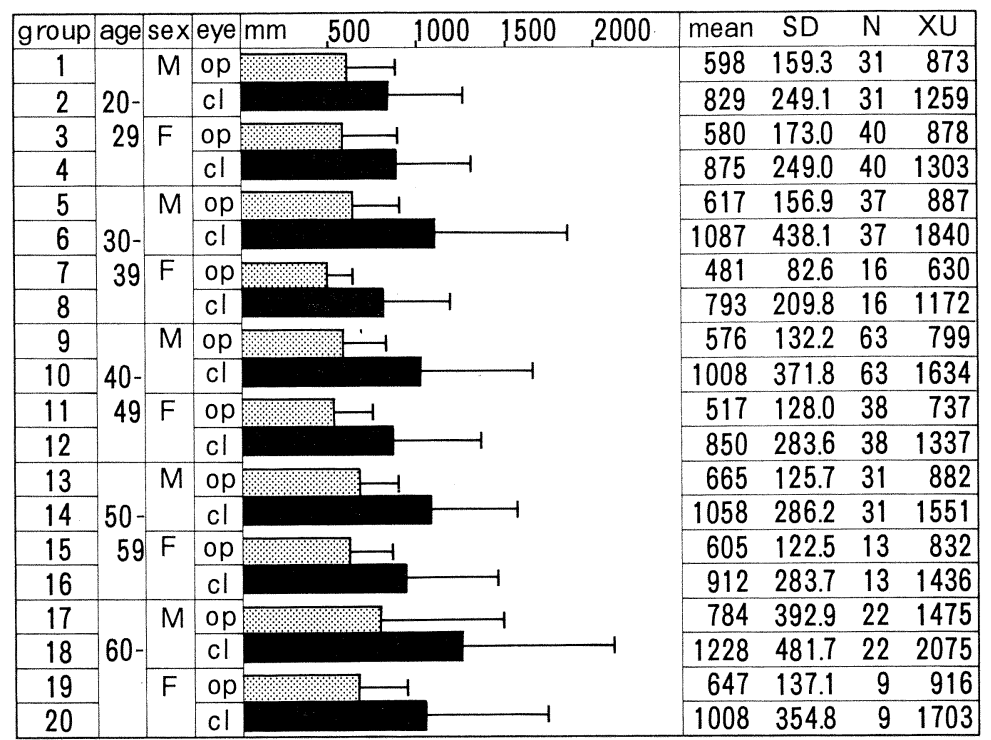

年齢 (age), 性別 (M : 男, F : 女), 開眼 (op), 閉眼 (cl), 平均值 (mean), 標準偏差 $(\mathrm{SD})$, 例数 $(\mathrm{N}), 95 \%$ 信頼限界上限 $(\mathrm{XU})$, 単位 $\mathrm{mm}$

表 2 正常者の動摇面積

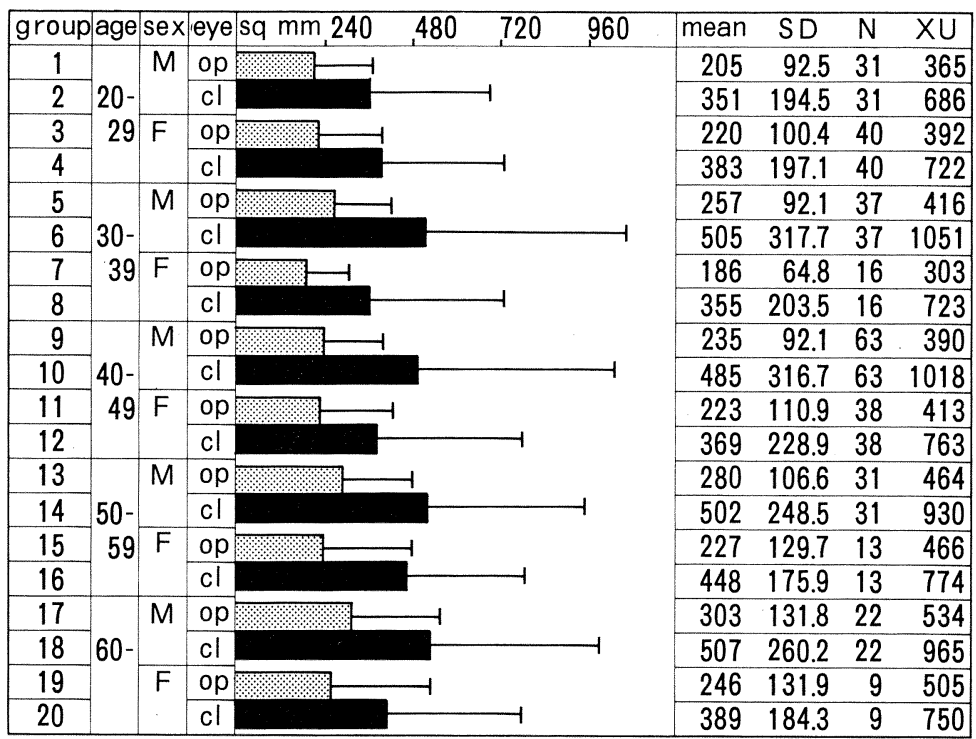

年齢（age）, 性別 (M: 男, F : 女), 開眼 (op), 閉眼 (cl), 平均值 (mean), 標準偏差 $(\mathrm{SD})$, 例数 $(\mathrm{N}), 95 \%$ 信頼限界上限 (XU), 単位 $\mathrm{mm}^{2}$

$\mathrm{mm}^{2}, 965 \mathrm{~mm}^{2}$ であった。また，60歳以上の平均值に対 して男性では開眼時に20，40歳代, 閉眼時に20歳代で有 意に（ $\mathrm{t}$ 検定， $\mathrm{p}<0.05 ）$ 減少したが，女性では開閉眼 とも有位差はみられなかった（表 2 ）。

\section{3. 左右方向動摇最大幅}

信頼限界上限は60歳未満では開眼最大 $35.4 \mathrm{~mm}$, 閉眼 最大 $49.0 \mathrm{~mm}$ で， 60 歳以上では，それぞれ， $35.6 \mathrm{~mm}$, $52.5 \mathrm{~mm}$ であった（表 3 )。 
表 3 正常者の左右方向動摇最大幅

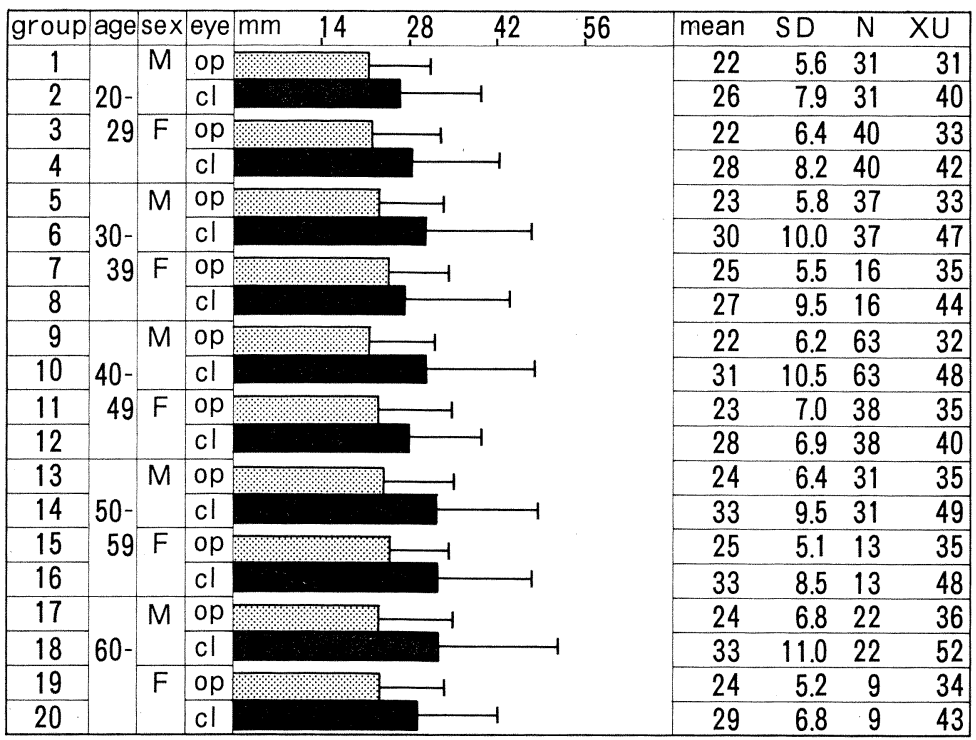

年齢 (age), 性別 (M : 男, F : 女), 開眼 (op), 閉眼 (cl), 平均值 (mean), 標準偏差 $(\mathrm{SD})$, 例数 (N), 95\%信頼限界上限 (XU), 単位 $\mathrm{mm}$

表 4 正常者の前後方向動摇最大幅

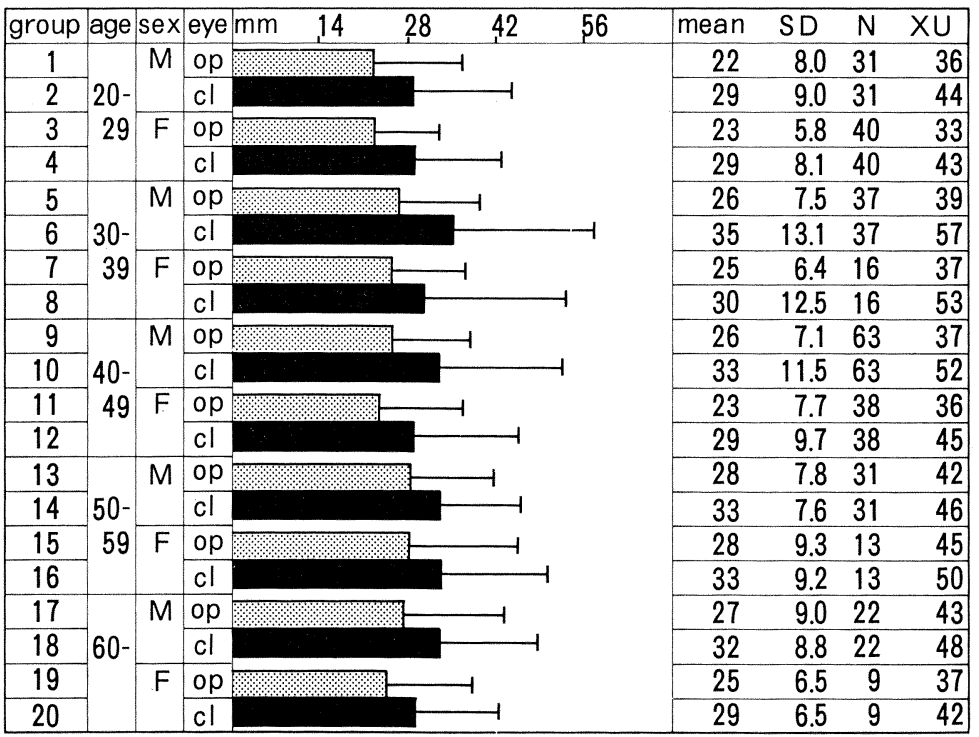

年齢（age），性別（M: 男， F : 女), 開眼 (op), 閉眼 (cl), 平均值 (mean), 標準偏差 $(\mathrm{SD})$, 例数 $(\mathrm{N}), 95 \%$ 信頼限界上限 $(\mathrm{XU})$, 単位 $\mathrm{mm}$

4. 前後方向動摇最大幅

上限は60歳未満では開眼最大 $45.0 \mathrm{~mm}$, 閉眼最大 57.2 $\mathrm{mm}$ で，60歳以上では，それぞれ，42.8 mm， $47.8 \mathrm{~mm}$ であった（表 4 ）。

\section{5. 周波数分析}

開眼, 閉眼問わず動摇の左右方向, 前後方向共低い周 波数側で高龄者は青壮年に比して，振幅スペクトラム值 の増加を示した（図1, 図 2, 図 3, 図4)。 


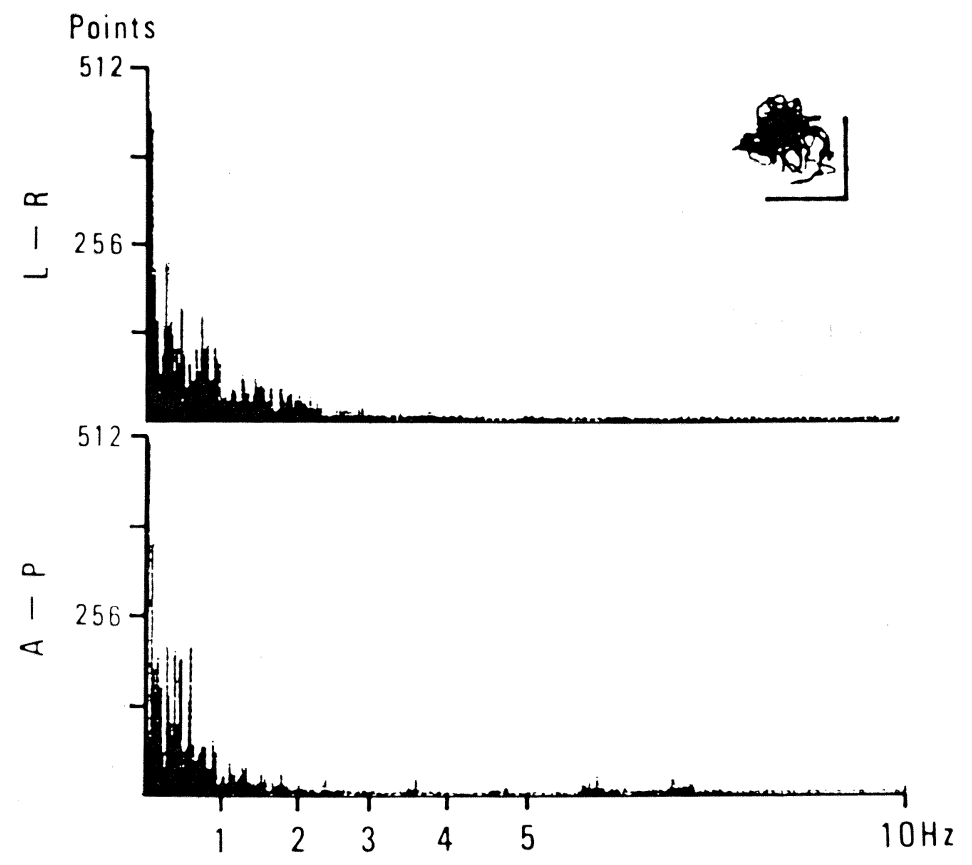

上段 $(\mathrm{L}-\mathrm{R})$; 左右方向の動摇 下段 $(\mathrm{A}-\mathrm{P})$; 前後方向の動摇 較正, $5 \mathrm{Nm}$

図 1 ロンベルグ姿勢の重心動摇図と振幅スペクトラム（正常被検者30歳男性, 開眼時)

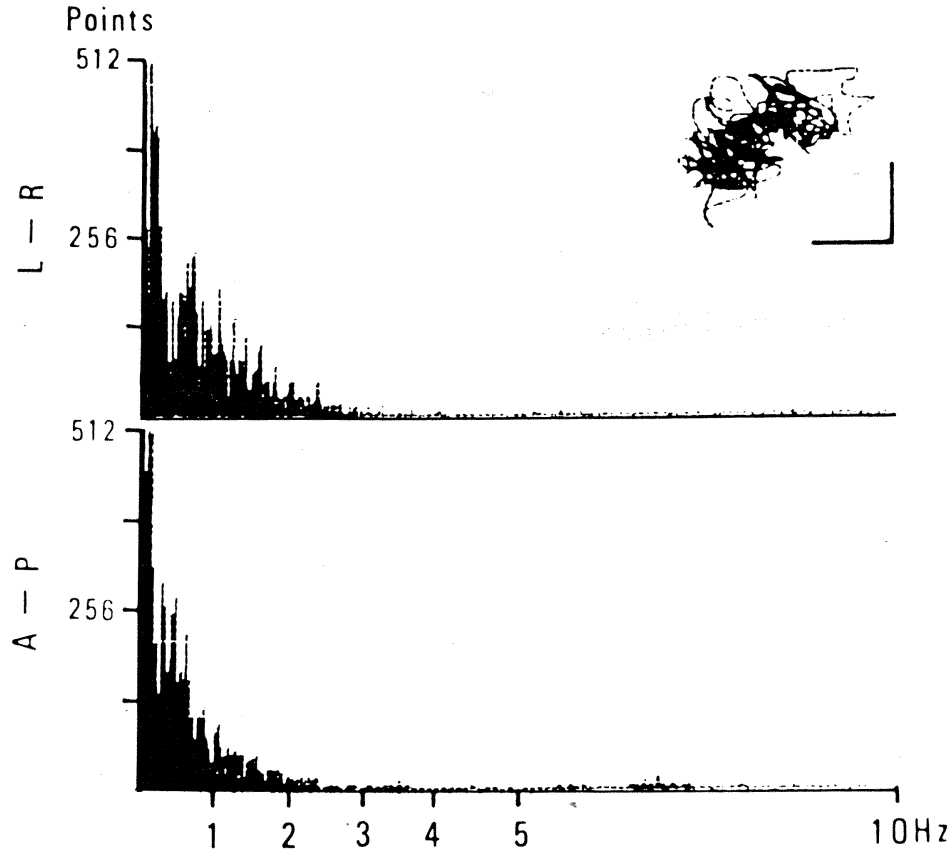

上段 $(\mathrm{L}-\mathrm{R})$; 左右方向の動摇 下段 $(\mathrm{A}-\mathrm{P})$; 前後方向の動摇 較正， $5 \mathrm{Nm}$

図 2 ロンベルグ姿勢の重心動摇図と振幅スペクトラム（正常被検者30歳男性, 閉眼時) 


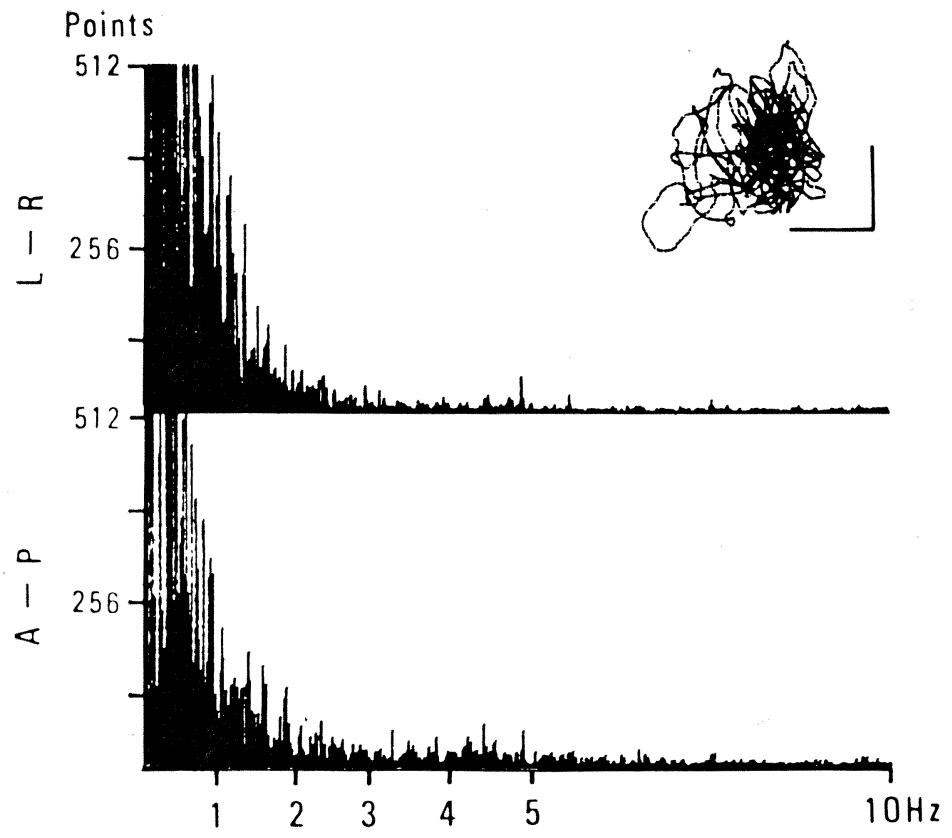

上段 ( $\mathrm{L}-\mathrm{R})$; 左右方向の動摇 下段 (A-P); 前後方向の動摇 較正, $5 \mathrm{Nm}$

図 3 ロンベルグ姿勢の重心動摇図之振幅スペクトラム（正常被検者73歳男性, 開眼時)

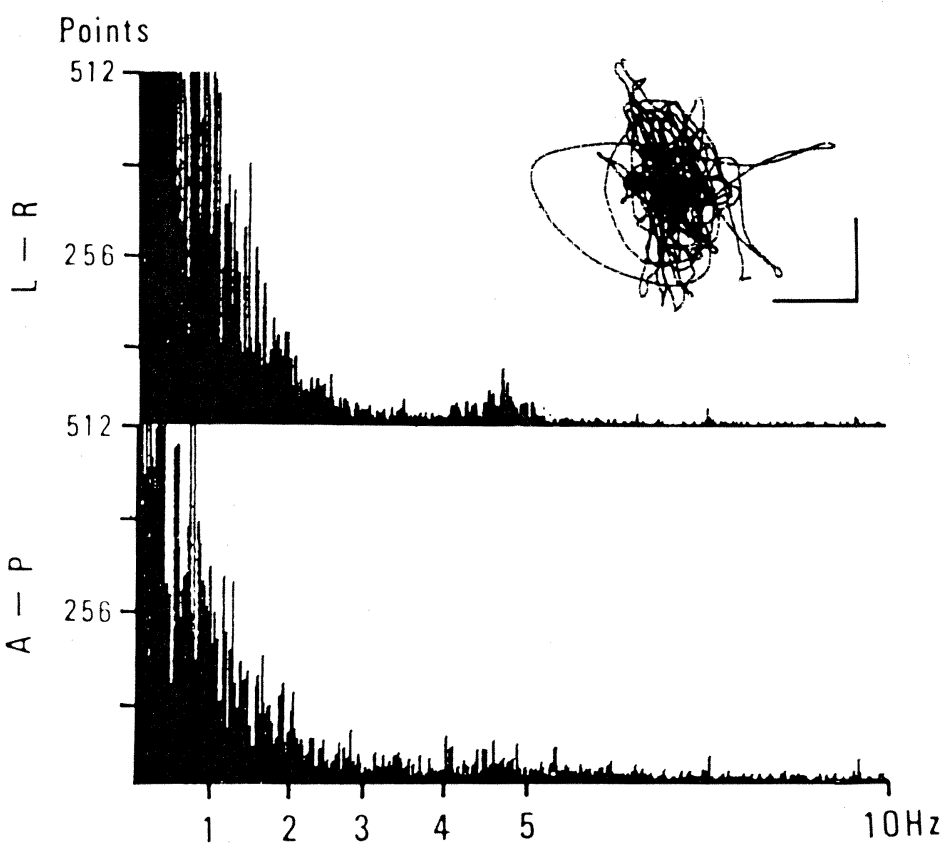

上段 $(\mathrm{L}-\mathrm{R})$; 左右方向の動摇 下段 $(\mathrm{A}-\mathrm{P})$; 前後方向の動摇 較正, $5 \mathrm{Nm}$

図 4 ロンベルグ姿勢の重心動摇図と振幅スペクトラム（正常被検者73歳男性, 閉眼時) 
表 5 左右方向の動摇に括ける各周波数帯域での百分率の平均值と標準偏差 $\quad\left({ }^{*} \mathrm{P}<0.01\right)$

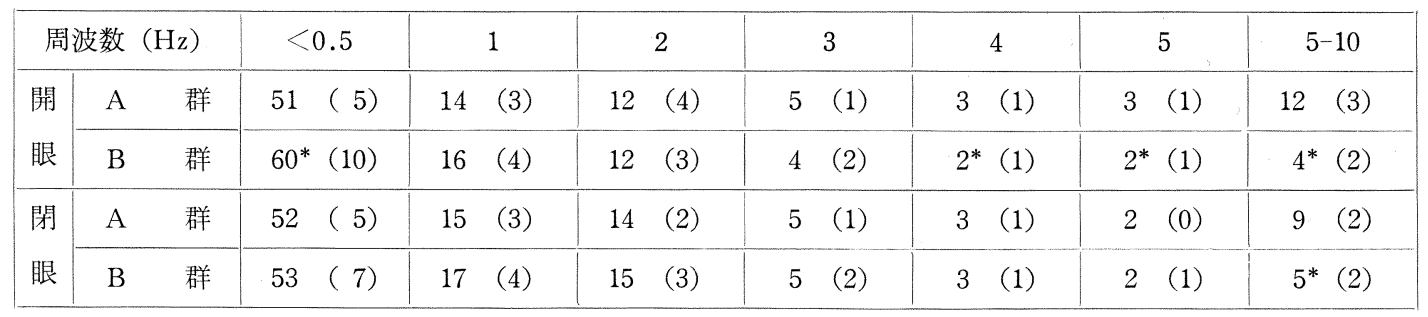

A 群は青壮年者（50歳未満20名）Ｂ群は高蔽者（65歳以上10名）

数值は平均值（）内は標準偏差 $10 \mathrm{~Hz}$ までの総振幅值に対する各周波数帯域の振幅和の百分率\%を示す。

表 6 前後方向の動摇における各周波数帯域での百分率の平均值と標準偏差 $\quad(* \mathrm{P}<0.01)$

\begin{tabular}{|c|c|c|c|c|c|c|c|c|c|c|}
\hline \multicolumn{3}{|c|}{ 周波数 $(\mathrm{Hz})$} & & .5 & 1 & 2 & 3 & 4 & 5 & $5-10$ \\
\hline 開 & A & 群 & & ( 8 ) & $10 \quad(3)$ & $9 \quad(2)$ & $4 \quad(1)$ & $3 \quad(1)$ & $3 \quad(1)$ & $14 \quad(3)$ \\
\hline 眼 & B & 群 & 58 & (13) & $14^{*}(4)$ & $12 \quad(5)$ & $5 \quad(2)$ & 3 (1) & $2^{*}(1)$ & $6^{*}(3)$ \\
\hline 閉 & A & 群 & 55 & (10) & $14 \quad(5)$ & 11 (4) & $4 \quad(1)$ & $3 \quad(1)$ & (1) & $10 \quad(2)$ \\
\hline 眼 & B & 群 & 51 & (13) & $16 \quad(5)$ & $15^{*}(5)$ & $6^{*}(2)$ & $3 \quad(2)$ & (2) & $6^{*}(4)$ \\
\hline
\end{tabular}

A群は青壮年者（50歳未満20名）Ｂ群は高齢者（65歳以上10名）

数值は平均值，（）内は標準偏差 $10 \mathrm{~Hz}$ までの総振幅值に対する各周波数帯域の振幅和の百分率\%を示す。

左右方向の動摇において, 高齢者のB群は青壮年の A 群に比して, 開眼時に拈いては, $0.5 \mathrm{~Hz}$ 未満での増大, 3-4 Hz，4-5 Hz，5-10 Hz での減少を認め，閉眼時にお いては，5-10 Hz での減少を認めた（ $\mathrm{t}$ 検定， $\mathrm{p}<0.01)$ (表 5 )。

前後方向の動摇においては, B群は $\mathrm{A}$ 群に比べ, 開眼 時に沶いては，0.5-1 Hz での増大， $4-5 \mathrm{~Hz} ， 5-10 \mathrm{~Hz}$ での減少を認め, 閉眼時に抢いては, 1-2 Hz, 2-3 Hz で の増大, $5-10 \mathrm{~Hz}$ での減少を認めた ( $\mathrm{t}$ 検定, $\mathrm{p}<0.01)$ (表6)。

\section{考案}

重心動摇検査で得られた測定值の正常域を定める場 合, 検查条件の基準化が必要であり, 今回, 日本平衡神 経科学会で推薦する標準的検査方法に従って検查を実施 した。また, 重心動摇記録の評価については, X-Y 記 録図の前後径, 左右径, できれば面積を計測するとされ ている。面積はプラニメータの測定を標準とするとし， 我々はこれらの基準に従った1)。動摇の大きさについて, 動摇軌跡距離もあわせて計測した。

田近 ${ }^{4)}$ は, 軌跡長について年龄, 性別に有意差はみら れなかったと報告しているが, 面積, 軌跡距離の平均值 は, 60 歳以上に対して 60 歳未満のいくつかの年齢群で 開閉眼とも有意に減少し, それは閉眼時より開眼時に多 く, 女性より男性に多かった。これらの年齡差や性差 は, 日常生活様式や神経筋機能の働きの違いなどに起因
するのではないかと推定された。面積, 軌跡距離, 左右 及び前後方向動摇について，いられも開閉眼差が認めら れた。性差については，20歳代では女性は男性より大き な值を示したが，高齡になるにしたがい男性では増加が みられ，女性は変化が減少し，60歳以上では女性より男 性が大きくなり逆転するにいたっている。池上5) は，末 梢前庭障害者では閉眼時の左右方向の動摇振幅は, 正常 者よりも大きいとし, 正常者について山本 ${ }^{6)}$ は, 閉眼 時, 加齢とともに前後方向よりも左右方向動摇が増加す るとし, 五島7) は, 左右方向に打いて70歳以上が有意に 大きいと報告しているが，今回我々が行った正常者の結 果も同様であった。

周波数分析については, $10 \mathrm{~Hz}$ まで必要か否かは現在 決定されていない1）が，18歳から49歳における群（A 群）と65歳から78歳に打ける群 (B群) を比較したとこ ろ, B 群はA群に比し, 前後方向, 左右方向の動摇にお いて, $2 \mathrm{~Hz}$ まででの増大, $5-10 \mathrm{~Hz}$ での減少の傾向が みられ，高齢者では，開閉眼時とも低周波数成分の増 大，高周波数成分の減少が認められた。立直り反射には 迷路, 視器, 自己受容器などの受容器と大脳, 小脳, 脳幹の中枢神経系ならびに骨格筋の運動系が関与してい $3^{899) 10)}$ 。高齢者で得られた直立時の特徵が, 小脳協調運 動の障害, 春髄反射の障害, 筋力の低下, 筋緊張の変化 等のいづれが関与しているかについては, 今後検討して ゆきたい。 


\section{結 論}

1. 正常被検者 300 名のロンベルグ姿勢開閉眼 1 分間の 直立時重心動摇検査を行い, 年代別, 性別に重心動摇軌 跡距離, 動摇面積, 左右方向および前後方向動摇最大幅 の95\%信頼限界上限を求めた。

2. 50 歳未満の青壮年 20 名（A群）と65歳以上の高歯会 10名 (B 群) について周波数分析を行い, 前後方向, 左 右方向の動摇のいづれに扣いても $\mathrm{B}$ 群はA 群に対して, $2 \mathrm{~Hz}$ まででの増大，5-10 Hz での減少の傾向が認めら れた。

本論文の要旨は, 第43回日本平衡神経科学会総会, 昭 和60年ワークショップ (平衡機能検査法の基準化並びに 診断学的貢献度）に扣いて発表した。

\section{文献}

1) 日本平衡神経科学会 ”平衡機能検査の標準化検討委 員会”：重心動摇検査の基準. Equilibrium Res 42 : 367-369, 1983

2 ) 伊保清子, 他 : ヒト直立時重心動摇記録図の井繞面 積と矩形面積との相関. Equilibrium Res 44:171175, 1985

3 ) 米田 敏, 徳増厚二: 正常人の直立時重心動摇の周 波数分析 (1) 一視覚 - 足底支持面の影響. Equilibrium Res 41: 55-60, 1982

4 ) 田近由美子: 重心動摇移動距離之重心動摇図 (X軸 長, Y軸長) についての研究. 金沢大学十全医学会 雑誌 $88(1): 122-137,1979$

5 ) 池上彰博 : 直立時重心動摇の振幅と速度の研究一年 齢变化と診断的意義. 日耳鼻 $86: 886-898,1983$

6 ) 山本高司：直立時動摇の年齢による変化. 体力科 学 $28: 249-256,1979$

7 ）五島桂子：重心動摇検査の検討一ユンピュータ分析 に抢ける検査項目之正常域. Equilibrium Res 45: 368-387, 1986

8 ）時田 喬, 他: 頭部並びに重心動摇記録計による立 直り反射検査. 耳鼻臨床 65：443-456，1972
9 ）長山郁生 : 重心動摇計による身体偏位の観察. 耳鼻 臨床 76:197-222, 1983

10) Watanabe $I$, et al: The role of the plantar mechanoreceptor in equilibrium control ANN N Y ACAD SCI $374: 855-864,1981$

\section{Abstract}

Stabilometry has recently become recognized as a useful way to evaluate human standing ability. However, the clinical evaluation of each parameter and its normal range in different age groups have not yet been determined.

The test, which was recommended by the Japan Equilibrium Research Association in 1983, was applied to 300 normal subjects in this study. Each subject was asked to stand in Romberg's posture on a force plate for one minute with eyes open and for one minute with eyes closed. The mean values, their standard deviations and the upper limits of the normal ranges of total length of movement of the center of gravity, sway area and maximum width of lateral and antero-posterior body sway, were obtained in male and female subjects of different ages.

It was statistically confirmed that the mean values in those over 60 years of age were larger than the values in younger groups. The frequency analysis of body sway showed a tendency towards increased amplitude in the frequency range less than $2 \mathrm{~Hz}$ and decreased amplitude in the frequency range between 5 and $10 \mathrm{~Hz}$ in the older group.

$\left(\begin{array}{l}\text { 原稿到着 : 昭和 } 62 \text { 年 } 5 \text { 月11日 } \\ \text { 別刷請求先 :八木一記 } \\ \text { 干 } 228 \text { 神奈川県相模原市北里 1-15-1 } \\ \text { 北里大学医学部耳鼻咽喉科学教室 }\end{array}\right)$

